\title{
Lipid proxies of hydroclimate driven by tropical Pacific Ocean in East Asian monsoon regions
}

\author{
ShuChEng XIE ${ }^{1 *}$, Michael L. GRIFFITHS ${ }^{2}$, \\ NATALIE J'. BURLS', JIAYI LU ${ }^{1}$ \\ ${ }^{1}$ State Key Laboratory of Biogeology and Environmental \\ Geology, China University of Geosciences, Wuhan \\ 430074, China (*correspondence: xiecug@163.com) \\ 2 Department of Environmental Science, William Paterson \\ University, Wayne, NJ 07470, USA \\ ${ }^{3}$ Department of Atmospheric, Oceanic \& Earth Sciences, \\ Center for Ocean-Land-Atmosphere Studies, George \\ Mason University, Fairfax, VA 22030, USA
}

Significant progress has been made in the reconstruction of paleo-temperatures from microbial lipids. However, it remains largely unknown if the microbial lipids can be used as proxies of hydroclimate. Hydrological conditions exert an important impact on terrestrial ecosystems and thus it is of significance to decipher the evolutionary history of hydroclimate in monsoonal regions, including both drought and flooding events.

For years, we have established a series of microbial proxies of hydroclimate which could be used in terrestrial archives, including loess-paleosol, peat deposits, lacustrine sediments, and stalagmites [1]. Recently, we proposed that the relative abundance of archaeal to bacterial tetraethers could be used to identify extreme drought events in ancient times [2].

Here we present two examples to show the potential of the lipid proxies in the investigation on hydroclimate across East Asia. Both the drought events during the last four ice age terminations in North China, and the presence of the rainfall tripole pattern on tectonic timescales, have been documented by the lipid proxies to be driven by the tropical Pacific Ocean, which were not recorded by other proxies.

[1] Xie et al. (2013) Geology 41, 827-830. [2] Tang et al. (2017) EPSL 479, 98-107. 